\title{
Mapping the impacts of farmed Scottish salmon from a life cycle perspective
}

\author{
Richard W. Newton ${ }^{1}$ (D) - David C. Little ${ }^{1}$
}

Received: 10 March 2017 / Accepted: 2 August 2017 /Published online: 14 August 2017

(C) The Author(s) 2017. This article is an open access publication

\begin{abstract}
Purpose The European Union relies on seafood imports to supply growing demand that European production has failed to meet. Politically motivated media reports have denigrated competing imports in favour of local production. While life cycle assessment (LCA) measures global impact of value chains, it often fails to contextualise them. Using LCA, this article takes farmed Scottish Atlantic salmon as a case study of "local" production to identify and map the contributions to global environmental impact.

Methods Data on the Scottish salmon value chain were collected by structured survey from a large international feed mill, six farms and a major processor. Secondary data were collected from available literature on feed ingredients and background data from EcoInvent2.2. A mid-point CML2001 approach was adopted focussing on global warming potential (GWP), acidification potential (AP), eutrophication potential, ozone depletion potential, photo-chemical oxidation potential, consumptive water use and land use. Results were displayed as contribution analyses of materials and processes and mapped geographically using area plots.

Results and discussion Far from being a "locally" produced commodity, nearly $50 \%$ of the feed ingredients were sourced from South America and less than 25\% originated in the UK.
\end{abstract}

Responsible editor: Nils Jungbluth

Electronic supplementary material The online version of this article (doi:10.1007/s11367-017-1386-8) contains supplementary material, which is available to authorized users.

Richard W. Newton

rwn1@stir.ac.uk

1 Institute of Aquaculture, University of Stirling, Stirling FK9 4LA, UK
It was found that over $90 \%$ of the impact to farm-gate was embodied in feed, apart from eutrophication potential which was high at the farm from direct nitrogenous emissions into the marine environment. The majority of impacts do not occur in Scotland, particularly for land and water use, which occur at a more geographically significant level than GWP or AP, which are more global or regional impacts, respectively. High GWP emissions from vegetable-based ingredients were related to soil management and energy intensive processes such as wet milling to produce gluten from wheat and maize, sunflower and rapeseed oil processing.

Conclusions The results show that in an age of globalised commodity trading, concerns around "local" production are often misleading. As consumers try to make more responsible purchase choices, they may be misled over the global impacts their choices are having. There are clearly trade-offs between different feed ingredients, especially regarding substitution of marine ingredients with those of vegetable origin. While marine ingredients perform comparatively well, they are highly limited, and biodiversity impacts of different ingredients are less clear and difficult to compare.

Keywords Atlantic salmon · Impact mapping $\cdot$ LCA $\cdot$ Local production $\cdot$ Scotland

\section{Introduction}

The European Union is becoming ever more reliant on seafood imports to supply growing demand that European fisheries and aquaculture have failed to meet (Little et al. 2012). Politically motivated media reports have made claims that competing seafood imports may be associated with environmental and social concerns, and the EU should be seeking to import less, in favour of promoting growth in European 
aquaculture. This aligns with current consumer interests in consuming "local" food as a lifestyle choice (Janßen and Langen, 2016). However, as trade becomes more globalised, and competition for resources increases, raw materials for livestock production are increasingly sourced on a global basis, which inevitably result in environmental trade-offs (Ziegler et al. 2016).

Apart from smolts (juveniles), Scottish Atlantic salmon (Salmo salar) is produced exclusively in net pen systems in sheltered marine lochs or bays. Production started in the 1970s, increased quickly during the 1980s and 1990s but subsequently plateaued due to production challenges and increased competition for suitable sites with other stakeholders. Recently, production has begun to increase as the Scottish government has set a target to produce over 200,000 t of salmon by 2020 (http://www.gov.scot/Topics/marine/FishShellfish accessed 5/7/2017). Scottish salmon is now exported to over 60 countries worldwide (SSPO 2015) and is the second most valuable UK food export after whisky. In some circumstances, salmon aquaculture has raised environmental concerns from a number of standpoints, both locally and globally.

LCA is an ISO-accredited (ISO 2006a, b) environmental impact accounting tool which measures the cumulative impact throughout a product's value chain, covering a range of different environmental impacts. Several LCAs of salmon have been conducted in the past, notably Pelletier et al. (2009), Ayer and Tyedmers (2009), Torrisen et al. (2011) and McGrath et al. (2015). Some other LCAs have focussed on salmonid feeds such as Papatryphon et al. (2004) and Boissy et al. (2011). Of all the studies related to salmon, only Boissy et al. (2011) included water consumption and land use, and none of them attempted to map the various impacts throughout the value chain (VC), i.e. the connected and interrelated nodes of an industry that create and add value (Dey et al. 2015). Troell et al. (2014a) identified water footprints from a life cycle perspective as an important issue in the assessment of mariculture systems. In previous LCAs of salmon VCs, the vast majority of environmental impact has been associated with feed ingredient sourcing (e.g. Pelletier and Tyedmers 2007; Pelletier et al. 2009). Indeed, it has been estimated that around a third of agricultural land use may be devoted to providing livestock feed ingredients (Robinson et al. 2011) of which aquaculture represents an estimated $4 \%$ (Troell et al. 2014b).

Aquaculture feed formulators source ingredients from a global pool of resources such as marine ingredients from South America, which may represent as much as $40 \%$ of the diet by volume. Efforts to replace marine ingredients, which are regarded as being highly limited (Naylor et al. 2009; Ziegler et al. 2016), have resulted in greater substitutions of vegetable-based proteins, especially those derived from soybean which is critical for many European livestock feeds
(FAO 2006), including for aquaculture (FAO 2006; Torrisen et al. 2011). The vast majority of European-sourced soybean meals and concentrates are also from South America and have been connected to environmental concerns around deforestation of sensitive habitats for agricultural expansion (FAO 2006; Robinson et al. 2011; Tritsch and Arvor 2016; da Costa et al. 2017). Some vegetable-based feed ingredients have also been shown to be highly energy intensive in their processing compared to the marine ingredients which they substitute for (Boissy et al. 2011; Pelletier et al. 2009). There are clearly trade-offs between different impacts with regard to water, land, energy use and their associated emissions and impacts, but also to how impacts are geographically distributed. This is particularly the case for comparing between marine ingredients with low demands, especially on land and agricultural ingredients with potentially high land and water demands. Many aquaculture LCAs have presented a comprehensive set of environmental impacts but have often lacked contextualisation of these impacts from a local or global perspective and the implication for improvements or decision making, and it can be argued that a lack of regionalised/ localised impact assessment is common throughout LCA. Several studies have investigated regionalised impacts through LCA (e.g. Schlich and Fleissner 2005; Boulay et al. 2011; Patterson et al. 2011), and some efforts have been made to combine LCA with GIS methodology (e.g. Geyer et al. 2010; Gasol et al. 2011; Dresen and Jandewerth 2012; Mutel et al. 2012); however, these have not been frequently applied and only a few LCA studies have represented data geographically. Other challenges have arisen in how to measure the impacts of land use change related to the dependence of land required for agricultural expansion (Mila i Canals et al. 2007). Different approaches are being developed to measure the impacts of land use change (LUC) such as UNEP-SETAC initiatives, although consensus on regional factors (Nordborg et al. 2017) and effects on carbon sequestration (Nguyen et al. 2010) amongst others remain areas for debate. A summary of the challenges in characterising the impacts from land use and land use change are given by Nordborg et al. (2017). However, the authors of this paper regard LUC as more of an end-point issue and for that reason, as well as the complexities involved which we regard as out of scope, this article will focus only on land use rather than the effects of change.

\section{Goal and scope}

\subsection{Scope}

The aim of this paper is to view and compare the contributions to the environmental impacts of Scottish salmon production through process-based and geographical-based lenses to offer insights and contextualisation. Particularly, we identify 
emissions and demands on resources, which may be of more concern geographically rather than on a global basis, and compare local to global impacts. This may aid in identifying the most pertinent and achievable areas for improvement than contributions from processes alone.

\subsection{Functional unit, boundaries, allocation and uncertainty}

The functional unit of this study is $1.0 \mathrm{t}$ of head-on gutted (HOG) Atlantic salmon, boxed in ice at the primary processor gate. Primary data collection included the feed mill, production sites and the primary processor, whereas feed ingredient production and processing data were from literature sources. More details on the data collected are given in Sect. 3.

According to ISO 14040 and 14044 guidelines (ISO 2006a and 14044b), this study subdivided multi-functional processes where possible, but used economic allocation for most multifunctional processes throughout, as there is a mix of nearwaste by-product production (e.g. viscera at the primary processor) and co-product production with several "target products" in other cases (such as fishmeal and fish oil at the reduction plant). Economic allocation was used as being most appropriate given the motivations of the industry at each point in the value chain and the dynamics of transitioning between waste and co-production (MacKenzie et al. 2017). However, as co-product allocation is often a contentious subject and results may differ considerably according to the method chosen (Pelletier and Tyedmers 2007; Ayer et al. 2007), a sensitivity analysis, using mass allocation, has been included in the supporting information.

This study presents contribution analyses only; therefore, no uncertainty is presented on impact values for any category. However, a Numerical Unit Spread Assessment Pedigree (NUSAP) was used to account for representativeness during horizontal averaging of literature data according to Henriksson et al. (2014a).

\subsection{Assessment method and impact categories}

This study uses a CML2001 mid-point attributional approach. All modelling was conducted on CMLCA software licenced by Leiden University using the EcoInvent 2.2 database for background data such as transport emissions. Impact categories used were chosen according to the most important categories for aquaculture according to Pelletier et al. (2007) which were as follows: global warming potential (GWP), acidification potential (AP), eutrophication potential (EP), ozone depletion potential (ODP), photochemical oxidation (PCO), with the addition of consumptive water use (CWU) and land use (LU). These impact categories are most suitable for measuring the cumulative impact of aquaculture and the trade-offs within the value chain from a local and global perspective. However, toxicity potentials were not included because many of the chemicals and therapeutants used in aquaculture have not been well characterised for LCA purposes. Similarly, net primary productivity (NPP) was not included because methods are still not well defined (Cashion et al. 2016), and often, the category does not indicate the sensitivity of biotic resources. Impacts on biodiversity are not included because in many circumstances, the effects are difficult to measure and/or characterise throughout the VC (e.g. Ford et al. 2012). A distinction was made between CWU and water dependence, where CWU was regarded as water that was consumed by the system and no longer available for other uses, irrespective of quality changes. Water dependence is a different issue and refers to water that an aquaculture system requires to maintain environmental services such as oxygen provision or effluent dilution. Such water may then be available for other uses such as municipal use, irrigation or industry depending on its qualities. In this case, only blue and green water use were considered, where green water is that precipitated or present in the soil and blue water is derived from irrigation. Total water requirements were calculated from crop rainfall requirements in millimetres, given by Brouwer and Heibloum (1986) and assumed to be provided either by precipitation or irrigation for this study. Rainfall was then extrapolated to the given yields per hectare to provide a CWU in cubic metres per tonne of production. The calculation was validated by applying it to available water requirement data for crops given by Mekonnen and Hoekstra (2011) which were broadly in agreement, although their figures were towards the upper end of our calculated range. Unlike Mekonnen and Hoekstra (2011), we did not consider "grey" water requirements.

\section{Data collection and life cycle inventory}

Scottish salmon production is based exclusively in net pens in marine sites off the West Coast mainland, and the islands of the Outer and Inner Hebrides, Orkney and Shetland. At the time of data collection (2012 to 2014), smolts (juveniles) were produced to $70 \mathrm{~g}$ average, in freshwater sites before transportation to sea by road and boat. The fish were kept in 90-m circumference net pens for a period of around 22 months, at which point they reached an average size of around $4.5 \mathrm{~kg}$ before slaughter. Fish were transported by well boat from the production site to a slaughter station which may be combined with primary processing (gutting and bleeding). At this point, the head-on gutted (HOG) salmon were sent for further processing, either domestically or abroad.

All data collection was anonymous due to confidentiality agreements between ourselves and the companies involved. Primary data were collected using structured surveys in faceto-face interviews at the company locations. Secondary data 
were used for the production of feed ingredients and horizontally averaged according to Henriksson et al. (2014a). Data on emissions from managed soils were calculated according to IPCC (2006). Data on electricity mixes for each country or region in Table 1 were collected from the International Energy Authority website (IEA accessed 24/2/2014), and associated emissions from energy provision and transport were taken from the Ecoinvent database 2.2.

Primary data were collected from a major Scottish-based aquafeed mill which also has representation in other major salmon-producing countries. This included individual ingredients and quantities for standard grow out feed for 1 year of supply (2012), all electricity, gas, water consumption and land area. The data provided the quantity of each ingredient in the formulation and the location from which it was sourced, although specificity of location was variable. The source of some ingredients could be located to the county level, but for others only to the broad geographical region (e.g. "continental Europe"). The individual feed ingredients and their origins have been included in Table 1, but quantities have been shown aggregated, due to the wishes of the company, into broader categories such as marine proteins, vegetable oils etc.

Feed ingredient production and processing, data were taken from literature sources which provided information on fertiliser application, fuel use in machinery, other energy use, yield per hectare and chemicals used for separation and refining (Table 1). Road and ocean transport distances were calculated from Google Maps. Of the crop production data, only a few sources included freshwater requirements for those crops. Data on fishmeal and fish oil from Peru were from Henriksson et al. (2014b) adapted from Avadí et al. (2014) whereas the Danish fishmeal and fish oil were adapted from the same process with the energy mix and transport adjusted accordingly.

Farm data was collected from six individual sites, although some shared land bases and some other resources, such as boat use. Data were collected on quantity of feed used, electricity use, diesel for boats and service barges, fish mortality, medications, road distances from the shore base to the feed supplier, land occupation of the shore base and total salmon production. The weighted mean economic feed conversion ratio (eFCR) between the six farms was calculated at $1.19 \pm 0.10 \mathrm{~kg}$ of feed per $\mathrm{kg}$ of fish growth including fish losses. Medications for salmon production have not been widely characterised, and in this case, a pesticide process was used from the Ecoinvent database (Frischknecht et al. 2005). Data on the production of smolts were not collected in this instance; it was assumed that their contribution to overall impacts would be minimal, being only $1.5 \%$ of the size of the final product at stocking. Finally, data was collected on the primary processing of salmon, which included gutting and packing in ice within polystyrene boxes, prior to transport for further processing.

\section{Results}

A contribution analysis of processes and raw material inputs is shown in Fig. 1. Most impacts at the feed mill are from the
Table 1 Ingredient list and origin of ingredients included in growout salmon feed used in this study

\begin{tabular}{llll}
\hline Ingredient category/\% & Ingredient & Country of origin & Transport type \\
\hline Marine meals & Fishmeal $^{1}$ & Peru & Oceanic freight/road lorry \\
$25.9 \%$ & Fishmeal $^{1}$ & Denmark & Oceanic freight/road lorry \\
Marine oils & Fish oil $^{1}$ & Peru & Oceanic freight/road lorry \\
$22.0 \%$ & Fish oil $^{1}$ & Denmark & Oceanic Freight/road lorry \\
Vegetable proteins/fillers & Soybean meal $^{1,2,3}$ & Brazil & Oceanic freight/road lorry \\
$44.8 \%$ & Maize gluten $^{1}$ & Europe & Road lorry \\
& Wheat gluten $^{1}$ & Europe & Road lorry \\
& Fava beans $^{4}$ & UK & Road lorry \\
& Sunflower seed cake & Ukraine & Oceanic freight/road lorry \\
& Whole wheat $^{1,8,9,10}$ & UK & Road lorry \\
& DDGS $^{1,4}$ & UK & Road lorry \\
Vegetable oils & Rapeseed oil $^{5,11,12,13,}$ & UK & Road lorry \\
Vitamin and minerals & & & \\
$1.5 \%$ & & UK & Road lorry \\
\hline
\end{tabular}

Ingredients were modelled according to the following references: (1) Henriksson et al. 2014b, (2) Dalgaard et al. 2008, (3) Fitwi et al. 2013, (4) Frischknecht et al. 2005, (5) Iriarte et al. 2010, (6) Spinelli et al. 2013, (7) Spugnoli et al. 2012, (8) Hererra Huerta et al. 2012, (9) Wang et al. 2014, (10) Williams et al. 2010, (11) Iriarte et al. 2011, (12) Schmidt 2010, (13) Felten et al. 2013 

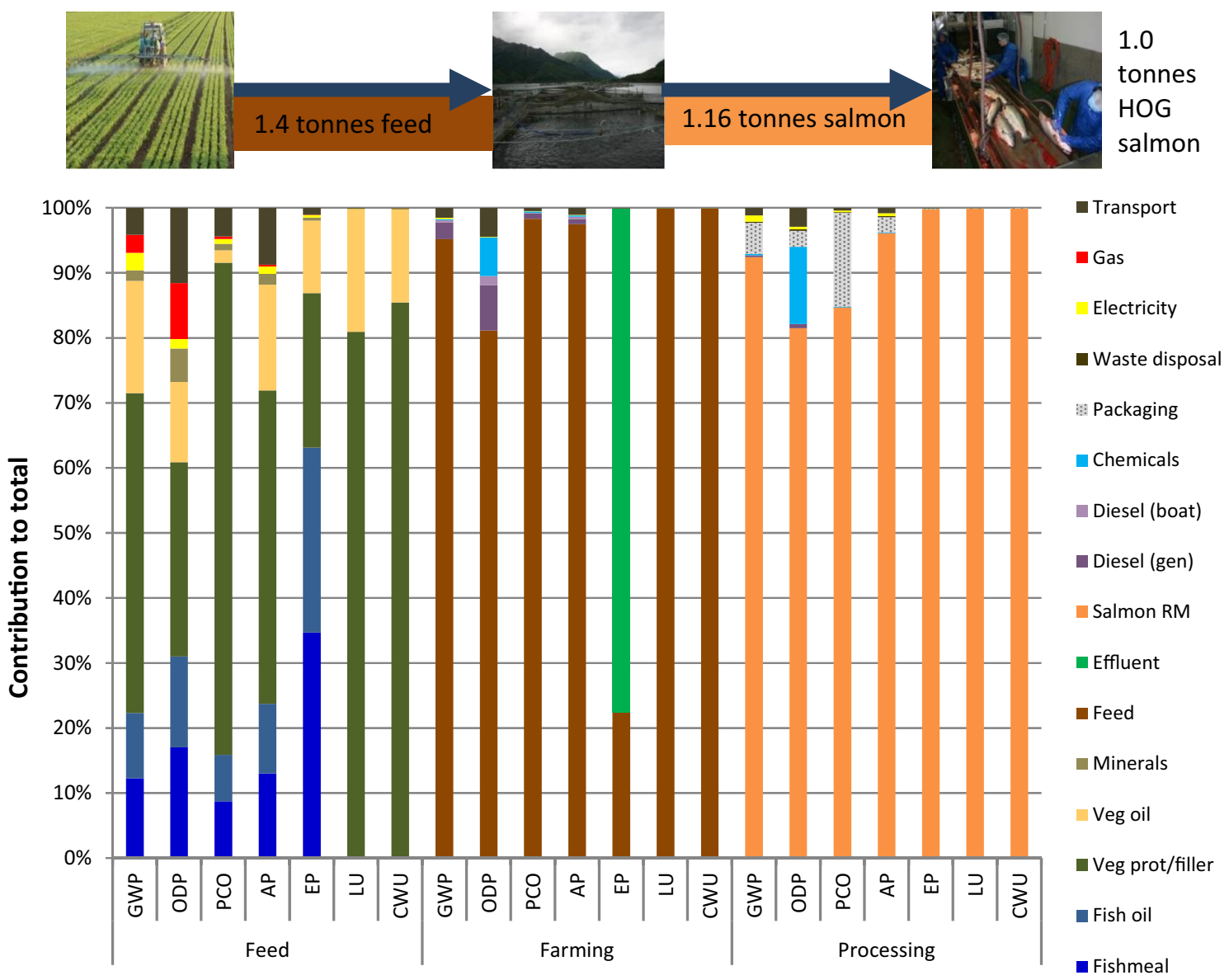

Fig. 1 Split contribution analysis for producing head-on gutted salmon at the primary processor, showing individual contributions at the feed mill, production site and processor. GWP global warming potential, $P C O$

embodied impacts of feed ingredient production. Marine ingredients contributed a relatively small amount to overall impacts from feed production, compared to their inclusion rate within the diet, for all categories except for eutrophication. The high eutrophication impact is explained by the nutrientrichness of effluent from fishmeal and fish oil production, which contains significant amounts of protein and lipid rich bloodwater (UNEP 2000). However, in terms of energy, requirements for fishmeal and fish oil production are low compared to that of some vegetable-based ingredients, particularly maize gluten and rapeseed oil, both of which feature within the diet formulation. It can be seen that most of the impacts at the feed mill stage are over represented by vegetable ingredient inclusion, especially oils which only form less than 5\% of the diet, but contribute to $18.0 \%$ of GWP, $16.9 \%$ of AP, $12.7 \%$ of PCO and $11.3 \%$ of EP. In the case of both CWU and LU, vegetable ingredients collectively contribute to over $99.7 \%$ of each category. Therefore, with increased substitution of marine ingredients with refined vegetable ingredients, the overall impacts of feed production would be expected to increase.

Feed is by far the most important contributor to impacts throughout the value chain (Fig. 1), as the embodied impacts photochemical oxidation, $A P$ acidification potential, $E P$ eutrophication potential, $L U$ land use, $C W U$ consumptive water use, $R M$ raw material

of feed production account for more than $80 \%$ of all impact categories, and this finding is supported in other salmon LCAs (e.g. Ayer and Tyedmers 2009; Pelletier et al. 2009; McGrath et al. 2015). An exception is EP, where the majority of impacts come from the metabolites of salmon growth, on the production unit. Apart from feed, notable impacts on ozone depletion potential occur from chemical usage at both the farm and at the processor. On the farm, this is connected to the production of medicinal treatments, whereas at the processor, it is the use of refrigerants which is of most concern. Minor but significant contributions to ozone depletion potential also occur through diesel used on the service barges and boats at the farm site. Notable contributions also occur from packaging materials at the processor, to PCO and GWP. However, these contributions are dwarfed by the direct and indirect contributions from feed production through to the salmon raw material at the processor. Contributions are often affected by the allocation procedure that is adopted (e.g. Pelletier and Tyedmers 2007), and so, a sensitivity analysis was conducted using mass allocation to test whether this had a significant influence on either the overall impact or the contributions to those impacts, particularly from different feed ingredients. The detailed results of 
this analysis can be found in the supporting information (Figs. $\mathrm{S} 1$ and S2, Tables S1 and S2, Electronic Supplementary Material), but generally, there were minor differences, both in the overall impact and in the contributions between the two allocation methods. Generally, mass allocation showed slightly lower overall impacts in all categories except land and consumptive water use which were higher using mass allocation. Consequently, the contributions to these two categories change most, from both the input processes and geographically, between the two allocation methods.

If we take these contributions from the process level and plot them geographically (Fig. 2), we can see how the emissions relate to the manufacture of the raw materials used within the salmon production unit and processor. If we consider that feed contributes to over $80 \%$ of emissions in each category, apart from EP, to the farm gate and over $80 \%$ of the emissions at the processor are accounted for by the embodied impacts in the salmon raw material in each category, the influence of feed ingredient supply can clearly be seen. Indeed feed indirectly accounts for over $80 \%$ of emissions in five of the seven categories studied up to the processor gate. Only for EP (22.4\%) and ODP (66.1\%) were the contributions less. A total of $77.4 \%$ of eutrophying emissions originate from the farm site from the excretions of the salmon with most other contributions coming from fishmeal and fish oil processing in Peru and Denmark. Small contributions to eutrophication were from agriculture to provide feed ingredients. Figure 2 demonstrates that far from being a local product, only $22.8 \%$ of feed ingredients were sourced from the UK with $44.1 \%$ of total normalised emissions, including $40.9 \%$ of total GWP and
Fig. 2 Geographical contribution analysis of Scottish farmed salmon production at primary processor gate

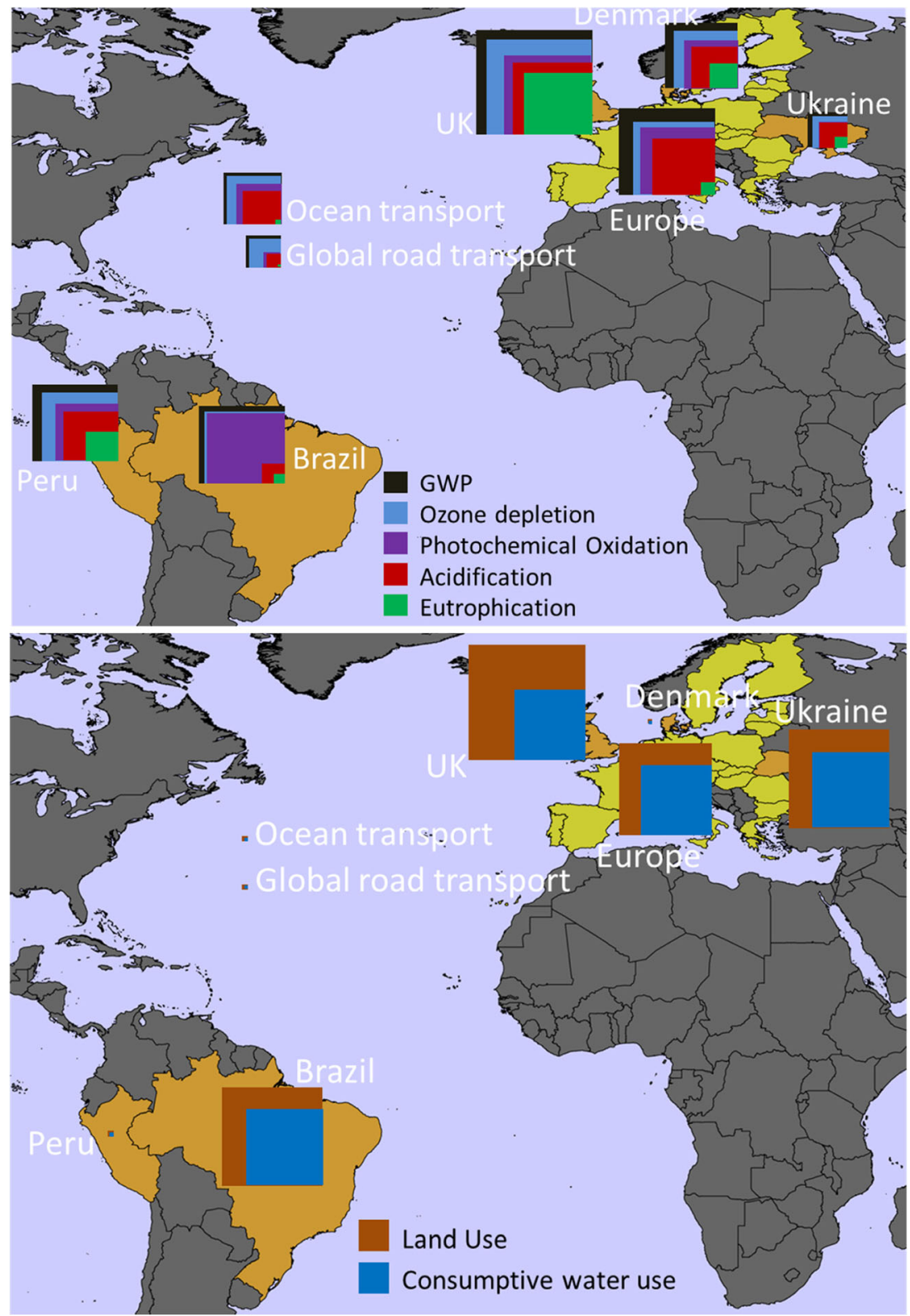


$59.9 \%$ of total ODP emissions. The largest contributor to both of these emissions in the UK relate to the production of rapeseed oil. Similarly, only $34.9 \%$ of CWU and $50.7 \%$ of land use was within the UK.

In Fig. 2, the geographic spread of emissions highlights disproportionate impacts from PCO in Brazil and from AP in continental Europe. The PCO contributions can be matched to vegetable protein production in Brazil which is attributable to land management and refinement of soy protein. High AP contributions in Europe are mostly linked to $\mathrm{SO}_{2}$ emissions from high energy inputs required for the processing of wheat and corn gluten, even though it makes up a relatively small proportion of the feed formulation. Whereas GWP and ODP may be considered of global importance, $\mathrm{AD}$ and $\mathrm{PCO}$ are of more localised and regional significance. Europe especially has a history of problems from acid rain dating back to early industrialisation, since when emissions from Western and central European countries have been linked to acidification effects in Central and Eastern Europe, Scandinavia and further afield (Menz and Seip 2004). Although significant steps have been made to reduce $\mathrm{SO}_{2}$ emissions in Europe, disproportionate contributions such as from gluten, which contribute $36.8 \%$ to AP at the feed mill stage, may be considered to be of concern. The effects of PCO from soybean cultivation and refinement are less clear, as the emissions are likely to be in more rural areas and dispersed more easily than in cities, and where it is less of a human health concern.

Of more concern in Brazil are perhaps the contributions to CWU and LU from soybean cultivation at 26.8 and $16.0 \%$, respectively. Concerns over clearance of sensitive rainforest habitats for agriculture in South America have been longstanding. Despite Schmidt (2010) arguing that the main driver of deforestation in Brazil is logging, at over four times that of agricultural expansion, according to Roberts et al. (2015), Brazil had the largest increase in land area devoted to agriculture of any country, between 2008 and 2013, at 73,000 $\mathrm{km}^{2}$, an area the size of the Republic of Ireland. The Ukraine, although smaller in size, had an expansion in agricultural land use of $16.6 \%$ in the same time period so that in $2013,34.5 \%$ of the country was devoted to agriculture. Such rates of expansion should raise concerns, as the changes will undoubtedly have large impacts on biodiversity as well as pressures on water resources for irrigation in some circumstances. High water demands were identified in the UK (34.9\%), for various feed ingredients, Brazil (26.8\%), from soybean production, Ukraine (26.2\%), from sunflower production, and continental Europe (12.1\%) also for various feed ingredients. The significance of this is dependent on the local situation as certain parts of these countries are more water stressed than others. Pfister et al. $(2009,2011)$ identified global areas of water scarcity and the proportion of abstracted water used for agriculture. Parts of the UK, Ukraine and continental Europe, where some feed ingredients were sourced, had water extraction rates up to five times higher than recharge, and therefore, formulators should be wary of using some of the more demanding of these crops as shown in Fig. 3. The water scarcity data referred to in this article, from Pfister et al. (2009, 2011), is being further developed into the AWARE methodology (http://www.wulcawaterlca.org/aware.html accessed 19/4/2017) and adopted into EcoInvent v3 (Pfister et al. 2016) along with measures to harmonise methodology with water foot-printing methodology (Pfister 2017). In addition, Boulay et al. (2011) have characterised water according to different quality characteristics which may be altered by human activities, and Boulay et al. (2015) further developed water use into end-point impact categories including human health. These methodologies may be further adopted to identify areas which may be highly impacted due to existing water scarcity issues, although the resolution may need to be increased to gauge the impact on a local scale. The sensitivity analysis using mass allocation, shown in detail in the supplementary materials, showed a higher consumptive water and land use demand, mostly as a result of the influence of sunflower seed cake in the diet. Consequently, the balance between vegetable oils and vegetable proteins in the contribution analysis shifted towards the protein and also geographically. The LU and CWU contributions from the Ukraine were raised significantly as a result (Table S2, Electronic Supplementary Material).

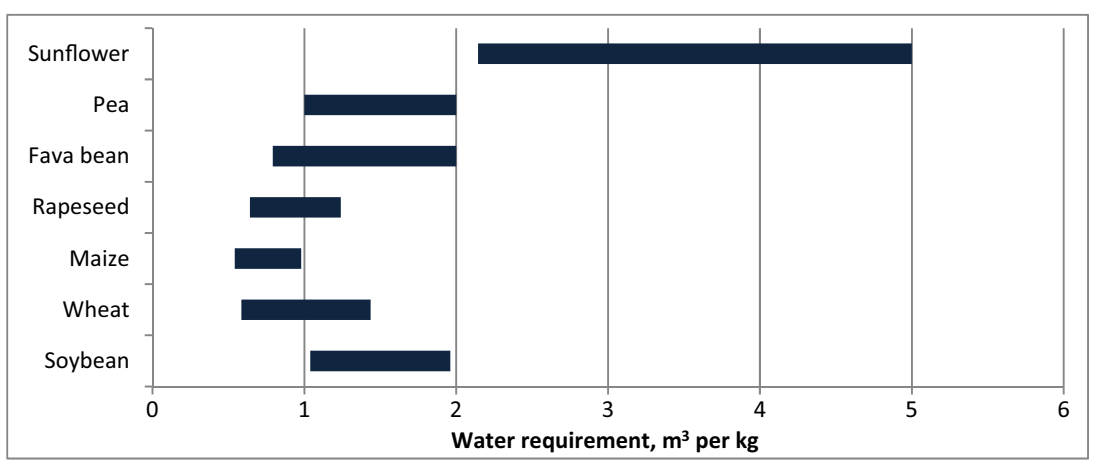

Fig. 3 Green and blue water requirement ranges for major feed ingredient crops, developed from rainfall requirements per hectare from Brouwer and Heibloum (1986) and crop yield data from Dalgaard et al. (2008), Hererra Huerta et al. (2012), Wang et al. (2014), Williams et al.
(2010), Murphy and Kendall (2013), Goglio et al. (2012), Iriarte et al. (2010), Spugnoli et al. (2012), Spinelli et al. (2013), Schmidt (2010), Iriarte et al. (2011), Felten et al. (2013) 
While this LCA study serves to highlight geographically disproportionate emissions and demands on resources, it is limited in detail to gauge the consequence of these impacts. The significance of emissions may be on a highly localised level, e.g. sensitive water body; regional level, e.g. land mass; or global level. For localised emissions, more contextual information may be necessary on the type of emission and the local conditions to assess whether the system can absorb those impacts without having an adverse effect on public health or wildlife. An example is if sea currents are adequate to disperse both dissolved and solid waste emitted from net pen sites or at a city level, how much PCO emissions are likely to cause public health issues. In order to do this, it would be necessary to normalise data to whatever level was necessary for the context of the emission and model its dispersion within that environmental system. These were considered end-point assessments, and while beyond the scope of this article, geographic information systems (GIS) could aid in identifying such issues. There have been a few efforts to integrate LCA and GIS in such a way that adds context to the ability of environmental systems to absorb localised/regionalised impacts or emissions, notably by Gasol et al. (2011), Dresen and Jandewerth (2012) and Mutel et al. (2012), but while offering interesting findings and setting out methodology and principles; so far, they have not been widely adopted.

Highly notable in this article is the difference in performance between marine and vegetable ingredients. Marine ingredients out-performed vegetable ingredients in most categories as shown in Fig. 4 and clearly seen in Figs. 1 and 2. However, the impacts on biodiversity have not been presented or discussed in this article. The trade-offs between impacts on marine vs terrestrial biodiversity are complex and challenging to measure in a single indicator. However, the impacts of reduction fisheries on marine ecosystems have been widely documented (e.g. Naylor et al. 2009; Alder et al. 2008), and although the majority of fishmeal comes from well-managed stocks, concerns are still held over its production. Fishmeal is widely considered to be at the limit of responsible production and the marine ingredients industry has been undergoing a period of change as increasing amounts of raw materials are sourced from the by-products of fisheries and aquaculture production so that now according to IFFO (The Marine Ingredients Organisation) as much as $35 \%$ of global supply originates from by-product. This trend looks likely to continue as the demand for fishmeal increases and the incentive to add value to by-products becomes greater. A report by IFFO (Jackson and Newton 2016) recently estimated that nearly 12 million tonnes of fishery and aquaculture processing byproducts were being wasted that could provide in excess of a further 2 million tonnes of fishmeal of various grades. However, responsible sources of marine ingredients will remain limited and other ingredients will continue to be required. Far from advocating that alternatives to fishmeal should not be sought, it is suggested that formulators should endeavour to find the best environmentally and socially responsible ingredients, as well as cost-effective, from the increasing range available. Key ingredients, such as fishmeals and fish oils, should be targeted to use in feeds for certain species and life stages where their use is most efficient, for example the use of finishing diets to improve omega- 3 fatty acid levels prior to harvest (Codabaccus et al. 2013). Although fishmeal is a globally traded commodity, inclusion level is often determined by cost and availability, and according to Henriksson et al. (2014b), some tilapia diets in Thailand contained up to $15 \%$ fishmeal from various sources. From a global life cycle perspective, this could perhaps be better

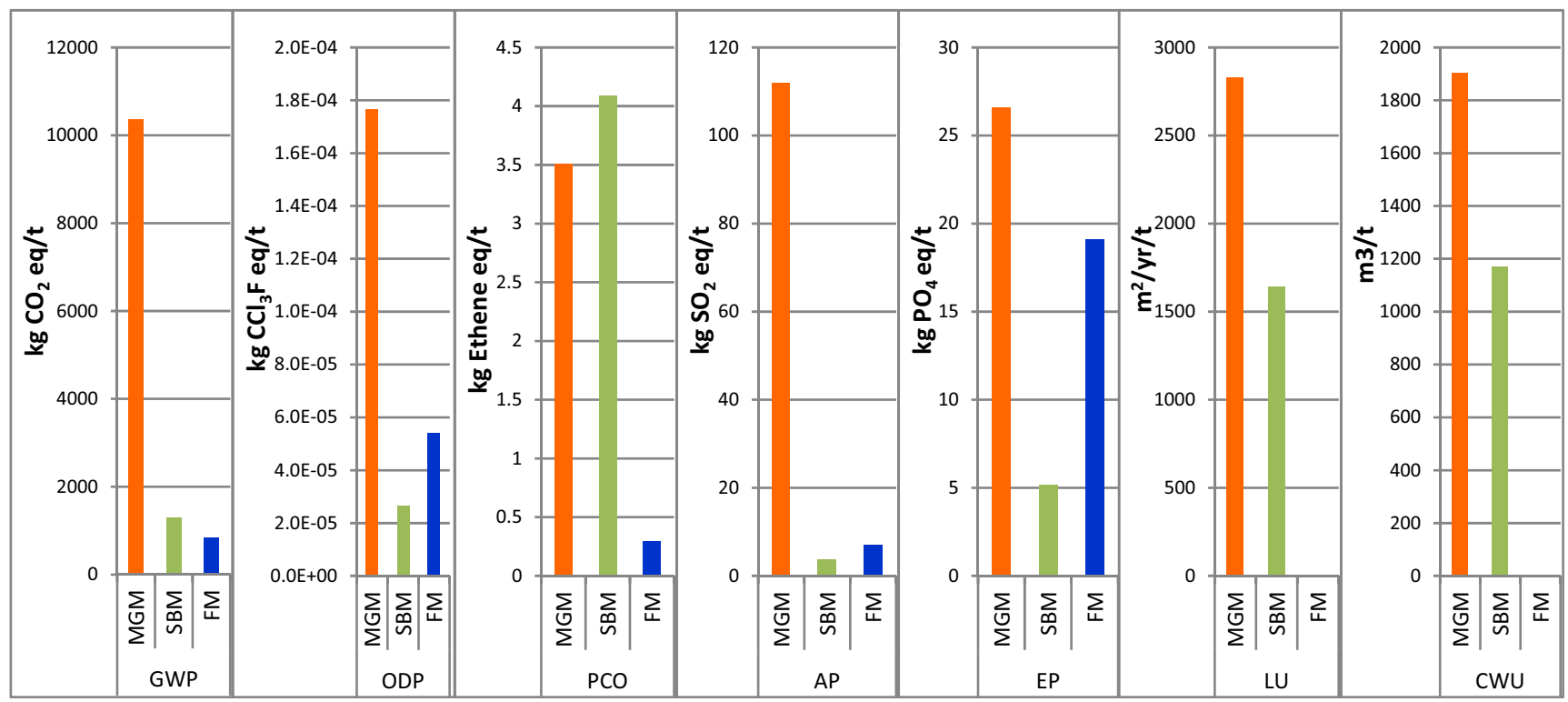

Fig. 4 Life cycle impact assessment of three major feed ingredients per tonne. $M G M$ maize gluten meal, $S B M$ soy bean meal, $F M$ fish meal 
utilised. New technology in marine ingredient processing, such as advanced enzymatic hydrolysis techniques, is enabling more efficiency and synergistic effects with other ingredients, through providing more advanced nutritional profiles than raw ingredients are able (Martínez-Alvarez et al. 2016). This has undoubted opportunities for the salmon aquaculture industry to improve its by-product utilisation strategy. Although there is virtually no wastage from UK processing activities, much is sent to fishmeal reduction as mixed byproduct where better separation and utilisation could potentially improve the value and add to the range of ingredients available for livestock nutrition. Viscera from primary processing are already hydrolysed into quality protein ingredients for tropical shrimp feeds, which has added value and ended a waste disposal issue for the salmon industry (Newton et al. 2014). Considering the dynamic situation regarding fishery and aquaculture by-products, this is potentially a fertile area for further LCA investigations.

In terms of overall improvements, rather than substituting small amounts of feed ingredients within diets, more substantial impact reduction can be made improving feed efficiency overall. Although there may be seasonal variability due to different challenges, improved feed efficiency has been the trend in most fin-fish aquaculture as demonstrated by Tacon and Metian (2015) and more improvements are to be expected, aided by such innovations in advanced ingredient development mentioned above. Further improvements have and could be made by improved automated feed delivery technology, genetic improvements, maturation control, better stock management and reduced mortality. Mortality is included when calculating eFCR, and improved survival can therefore substantially improve environmental performance, depending on when the majority of mortality occurs. Weighted mean mortality for the six farm sites in this study was $4.0 \%$ by weight, which is below the industry average estimated at between 5 and 10\% (SEPA 2004, Statistics Norway 2009) although the lowest mortality rate was just $1.0 \%$. Mortality continues to be a challenge for the industry particularly from sea lice which not only cause losses at the farm, but also at the processor, as consignments are rejected because of poor quality if lice counts exceed a specified number. As this problem is tackled, it is likely that the dynamics and trade-offs between different impacts may change. The lowest eFCR out of the six sites was 1.04 which is a $14.4 \%$ improvement on the average, although this site did not have the lowest mortality, suggesting that further improvements could be made. This would translate into substantial environmental impact abatement, if all farms were to achieve this benchmark of feed efficiency.

Also of note, is the minor contribution of transportation to any of the impact categories apart from ODP perhaps, to which ocean transport contributes $8.1 \%$. Such issues raise further questions as to whether so-called local production is "better" than food imports. When less than $25 \%$ of the raw materials are considered local, can the final product be considered as "locally produced"? Therefore, "food miles" should not be of concern to stakeholders from an environmental perspective, more the efficiency and responsibility of production within those countries prior to transport. That is, from an environmental impact perspective, it is preferable to source materials produced efficiently and cleanly from further afield than local materials produced inefficiently and with polluting practices. For example, Boissy et al. (2011) demonstrated that palm oil from Malaysia was preferable to German rapeseed oil in many impact categories. Although there may be genuine concern over the environmental impacts of global value chains in some circumstances, these may be unfounded and must be looked at in more detail on an individual basis.

A conscientious consumer may wish to buy locally produced food on the basis that they know it is responsibly produced from a food safety, environmental and social impact perspective. EU food law (EC 2002) and traceability generally ensure the safety of food produced within and imported to the $\mathrm{EU}$, but other responsibility issues are generally only covered by third party certification such as the Aquaculture Stewardship Council (ASC 2017). However, such certification schemes tend to focus on the production unit, with limited attention to whole value chain (Bush et al. 2013). This has led to issues elsewhere in the value chain being under-investigated. A recent example was the supply of fishmeal in Thai shrimp value chains, which was criticised for poor labour practices (https://www.theguardian.com/global-development/ 2014/jun/10/supermarket-prawns-thailand-produced-slavelabour, accessed 10/7/17). Whereas producers engaged with certification schemes that monitor shrimp farms, at the time, the monitoring did not extend to social practices throughout the $\mathrm{VC}$ and failed to pick up the problem. However, aquaculture has also been credited with improving the livelihoods of many vulnerable and/or remote communities, including rural populations on the West Coast of Scotland which has beneficial knock on effects throughout the value chain and associated communities (SSPO 2015). Such benefits to the local economy may out-weigh other considerations, especially when the global impacts of imported alternatives may be regarded as similar or more difficult to gauge. The choices made regarding food production, supply of materials, the knock-on environmental and social impacts and trade-offs are highly nuanced. However, retailers who advertise their produce as "local" have a duty to ensure and communicate the responsible credentials of their product from a value chain perspective, if consumers are purchasing the product on the basis that local production is ethically superior.

From a broader policy perspective, this study identifies the inadequacies of assessing the sustainability of food systems from highly localised, national standpoints alone. The study also highlights the need for balance between use of marine and terrestrial ingredients, and their resulting environmental impacts, in driving 
feed formulation for commodity food products such as farmed Atlantic salmon. The implications for global trade in food ingredients on policies supporting environmental restoration and conservation in both producer and consumer countries are also important, as has been noted for the telecoupled Brazil-China soybean trade (Torres et al. 2017)

\section{Conclusions}

This study shows that life cycle impact assessments can be strengthened by including more geographically specific data which enable contextualisation. To produce a fully integrated LCA/GIS study, a large dataset is required that details the characteristics of the environment where the emissions occur at each point in the value chain, so that the dispersion and assimilative capacity may be calculated. Such a dataset may not be practical to collect in the short term. However, efforts are being made by Global Feed LCA Institute (GFLI), constituted by a consortium of European feed associations, to build a feed ingredient LCA database using a standardised methodology developed by the FAO LEAP project (FAO 2016). Such a dataset may provide the necessary detail to facilitate GIS integration consistently. However, in this article, we have presented a practicable geographically contextualised result set which can be used to quickly highlight impacts of geographical concern which may then be investigated in more detail.

The study shows that Scottish salmon is not truly a "local" product but supports a vast global value chain. Consumers may be unaware that their support for local production, for environmental or other responsible production motivations such as socio-economic, food safety or animal welfare, is in fact supporting production on a much broader basis, and contributing to the associated impact that this may have or indeed benefits to those regions.

Open Access This article is distributed under the terms of the Creative Commons Attribution 4.0 International License (http:// creativecommons.org/licenses/by/4.0/), which permits unrestricted use, distribution, and reproduction in any medium, provided you give appropriate credit to the original author(s) and the source, provide a link to the Creative Commons license, and indicate if changes were made.

\section{References}

Alder J, Campbell B, Karpouzi V, Kaschner K, Pauly D (2008) Forage fish: from ecosystems to markets. Annu Rev Environ Resour 33:153-166

ASC (2017) ASC Salmon Standard Version 1.1 April 2017. Aquaculture stewardship council, Utrecht 103 pp

Avadí A, Vázquez-Rowe I, Fréon P (2014) Eco-efficiency assessment of the Peruvian anchoveta steel and wooden fleets using the LCA+ DEA framework. J Clean Prod 70:118-131
Ayer NW, Tyedmers PH (2009) Assessing alternative aquaculture technologies: life cycle assessment of salmonid culture systems in Canada. J Clean Prod 17(3):362-373

Ayer N, Tyedmers PH, Pelletier NL, Sonesson U, Scholz A (2007) Coproduct allocation in life cycle assessments of seafood production systems: review of problems and strategies. Int J Life Cycle Assess 12(7):480-487

Boissy J, Aubin J, Drissi A, van der Werf HMG, Bell GJ, Kaushik SJ (2011) Environmental impacts of plant-based salmonid diets at feed and farm scales. Aquaculture 321:61-70

Boulay A-M, Bulle C, Bayart J-B, Deschênes L, Margni M (2011) Regional characterization of freshwater use in LCA: modeling direct impacts on human health. Environ Sci Technol 45:8948-8957

Boulay AM, Motoshita M, Pfister S, Bulle C, Munoz I, Franceschini H, Margini M (2015) Analysis of water use impact assessment methods (part a): evaluation of water modeling choices based on a quantitative comparison of scarcity and human health indicators. Int J Life Cycle Assess 20(1):139-160

Brouwer and Heibloum (1986) Irrigation Water Management: Irrigation Water Needs - Part 1; Principles of Irrigation Water Needs. Chapter 2 - Crop Water Needs. Food and Agriculture Organisation of the United Nations, Rome. Available from: http:// www.fao.org/docrep/s2022e/s2022e02.htm\#chapter2: cropwaterneeds

Bush SR, Belton B, Hall D, Vandergeest P, Murray FJ, Ponte S, Oosterveer P, Islam MS, Mol APJ, Hatanaka M, Kruijssen F, Ha TTT, Little DC, Kusumawati R (2013) Certify Sustainable Aquaculture? Science 341:1067-1068

Cashion T, Hornborg S, Ziegler F, Skontorp Hognes E, Tyedmers P (2016) Review and advancement of the marine biotic resource use metric in seafood LCAs: a case study of Norwegian salmon feed. Int J Life Cycle Assess 21:1106-1120

Codabaccus MB, Ng W-K, Nichols PD, Carter CG (2013) Restoration of EPA and DHA in rainbow trout (Oncorhynchus mykiss) using a finishing fish oil diet at two different water temperatures. Food Chem 141:236-244

da Costa O, Matricardi E, Pedlowski M, Cochrane M, Fernandes L (2017) Spatiotemporal mapping of soybean plantations in Rondonia, western Brazilian Amazon. Acta Amazon 47(1):29-37

Dalgaard R, Schmidt J, Halberg N, Christensen P, Thrane M, Pengue WA (2008) LCA of soybean meal. Int J Life Cycle Assess 13(3):240-254

Dey M, Bjørndal T, Lem A (2015) Guest editors' introduction: value chain dynamics in aquaculture and fisheries. Aquac Econ Manag 19(1):3-7

Dresen B, Jandewerth M (2012) Integration of spatial analyses into LCA - calculating GHG emissions with geoinformation systems. Int J Life Cycle Assess 17:1094-1103

EC (2002) Regulation (EC) No 178/2002 of the European Parliament and of the Council of 28 January2002 Laying Down the General Principles and Requirements of Food Law, Establishing the European Food Safety Authority and Laying Down Procedures in Matters of Food Safety. http://eur-lex.europa.eu/LexUriServ/ LexUriServ.do?uri=OJ:L:2002:031:0001:0024:EN:PDF. 24 pp

FAO (2006) Livestock's Long Shadow. Food and Agriculture Organization of the United Nations (FAO), Rome $390 \mathrm{pp}$

FAO (2016) Environmental performance of animal feeds supply chains: guidelines for assessment. Livestock environmental assessment and performance partnership. FAO, Rome $141 \mathrm{pp}$

Felten D, Fröba N, Fries J, Emmerling C (2013) Energy balances and greenhouse gas-mitigation potentials of bioenergy cropping systems (Miscanthus, rapeseed, and maize) based on farming conditions in western Germany. Renew Energy 55:160-174

Fitwi BS, Meyer S, Reckmann K, Schroeder JP, Schulz C (2013) Aspiring for environmentally conscious aquafeed: comparative LCA of aquafeed manufacturing using different protein sources. J Clean Prod 52:225-233 
Ford JS, Pelletier NL, Ziegler F, Scholz AJ, Tyedmers PH, Sonesson U, Kruse SA, Silverman H (2012) Proposed local ecological impact categories and indicators for life cycle assessment of aquaculture: a Salmon aquaculture case study. J Ind Ecol 16(2):254-265

Frischknecht R, Jungbluth N, Althaus H-J, Doka G, Dones R, Heck T, Hellweg S, Hischier R, Nemecek T, Rebitzer G, Spielmann M (2005) The ecoinvent database: overview and methodological framework. Int J Life Cycle Assess 10:3-9

Gasol C, Gabarrell X, Rigola M, González-García S, Rieradevall J (2011) Environmental assessment: (LCA) and spatial modelling (GIS) of energy crop implementation on local scale. Biomass Energy 35: 2975-2985

Geyer R, Stoms DM, Lindner JM, Davis FW, Wittstock B (2010) Coupling GIS and LCA for biodiversity assessments of land use. Part 1: inventory Modelling. Int J Life Cycle Assess 15:454-467

Goglio P, Bonari B, Mazzoncini M (2012) LCA of cropping systems with different external input levels for energetic purposes. Biomass Bioenergy 42:33-42

Henriksson P, Guinée J, Heijungs R, de Koning A, Green D (2014a) A protocol for horizontal averaging of unit process data-including estimates for uncertainty. Int J Life Cycle Assess 19:429-436

Henriksson P, Zhang W, Nahid S, Newton R, Phan L, Hai D, Zhang Z, Andong R, Jaithang J, Chiamanuskul K, Son V, Hien H, Haque M, Kruijssen F, Satapornvanit K, Nguyen P, Phan L T, Liu Q, Liu L, Wahab M, Murray F, Little DC, Guinée J (2014b) Final LCA case study report primary data and literature sources adopted in the SEAT LCA studies, SEAT deliverable ref: D 3.5. EU FP7 funded project 222889. Available at: http://media.leidenuniv.nl/legacy/d35annexreport.pdf. $121 \mathrm{pp}$

Hererra Huerta J, Muñoz Alvear E, Montalba Navarro R (2012) Evaluation of two production methods of Chilean wheat by life cycle assessment (LCA). IDESIA (Chile) 30(2):101-110

IEA (2014) International Energy Authority Statistics https://www.iea.org/ statistics/statisticssearch/. Accessed 24 February 2014

IPCC (2006) N2O emissions from managed soils and CO2 emissions from lime and urea application, IPCC guidelines for National Greenhouse gas Inventories: vol 4, agriculture, forestry and other land use, Ch. 11. International panel on climate change, Geneva $54 \mathrm{pp}$

Iriarte A, Rieradevall J, Gabarrell X (2010) Life cycle assessment of sunflower and rapeseed as energy crops under Chilean conditions. J Clean Prod 18:336-345

Iriarte A, Rieradevall J, Gabarrell X (2011) Environmental impacts and energy demand of rapeseed as an energy crop in Chile under different fertilization and tillage practices. Biomass Bioenergy 37:4305-4315

ISO (2006a) Environmental management - life cycle assessment - principles and framework (ISO 14040:2006). ISO, Geneva $20 \mathrm{pp}$

ISO (2006b) Environmental Management - life cycle assessment - requirements and guidelines (ISO 14044:2006). ISO, Geneva $45 \mathrm{pp}$

Jackson A, Newton R (2016) Project to model the use of fisheries byproducts in the production of marine ingredients with special reference to omega-3 fatty acids EPA and DHA. A report by IFFO and the University of Stirling. IFFO, London $14 \mathrm{pp}$

Janßen D, Langen N (2016) The bunch of sustainability labels - do consumers differentiate? J Clean Prod 143:1233-1245

Little D, Bush S, Belton B, Nguyen P, Young J (2012) Whitefish wars: Pangasius politics and consumer confusion in Europe. Mar Policy 36:738-745

Mackenzie S, Leinonen I, Kyriazakis I (2017) The need for co-product allocation in the life cycle assessment of agricultural systems - is biophysical allocation progress? Int J Life Cycle Assess 22:128-137

Martínez-Alvarez O, Chamorro S, Brenes A (2016) Protein hydrolysates from animal processing by-products as a source of bioactive molecules with interest in animal feeding: a review. Food Res Int 73:204-212

McGrath K, Pelletier N, Tyedmers P (2015) Life cycle assessment of a novel closed-containment Salmon aquaculture technology. Environ Sci Technol 49:5628-5636
Mekonnen MM, Hoekstra AY (2011) The green, blue and grey water footprint of crops and derived crop products. Hydrol Earth Syst Sci 15:1577-1600

Menz F, Seip H (2004) Acid rain in Europe and the United States: an update. Environ Sci Pol 7:253-265

Mila i Canals L, Bauer C, Depestele J, Dubreuil A, Freiermuth Knuchel R, Gaillard G, Michelsen O, Müller-Wenk R, Rydgren B (2007) Key elements in a framework for land use impact assessment within LCA. Int J Life Cycle Assesss 12(1):5-15

Murphy C, Kendall A (2013) Life cycle inventory development for corn and stover production systems under different allocation methods. Biomass Bioenergy 58:67-75

Mutel C, Pfister S, Hellweg S (2012) GIS-based regionalized life cycle assessment: how big is small enough? Methodology and case study of electricity generation. Environ Sci Technol 46(2):1096-1103

Naylor R, Hardy R, Bureau D, Chiu A, Elliot M, Farrell A, Forster I, Gatlin D, Goldburg R, Hua K, Nichols P (2009) Feeding aquaculture in an era of finite resources. PNAS 106(36):15103-15110

Newton R, Telfer T, Little D (2014) Perspectives on the utilization of aquaculture co-product in Europe and Asia: prospects for value addition and improved resource efficiency. Crit Rev Food Sci 54(4): 495-510

Nguyen TLT, Hermansen JE, Mogensen L (2010) Environmental consequences of different beef production systems in the EU. J Clean Prod 18:756-766

Nordborg M, Sasu-Boakye Y, Cederberg C, Berndes G (2017) Challenges in developing regionalized characterization factors in land use impact assessment: impacts on ecosystem services in case studies of animal protein production in Sweden. Int J Life Cycle Assess 22:328-345

Papatryphon E, Petit J, Kaushik SJ, Van der Werf HMG (2004) Environmental impact assessment of salmonid feeds using life cycle assessment (LCA). Ambio 33(6):316-323

Patterson T, Esteves S, Dinsdale R, Guwy A (2011) Life cycle assessment of biogas infrastructure options on a regional scale. Bioresour Technol 102:7313-7323

Pelletier NL, Tyedmers PH (2007) Feeding farmed salmon: is organic better? Aquaculture 272:399-416

Pelletier NL, Ayer NW, Tyedmers PH, Kruse SA, Flysjo A, Robillard G, Ziegler F, Scholz AJ, Sonesson U (2007) Impact categories for life cycle assessment research of seafood production systems: review and prospectus. Int J Life Cycle Assess 12(6):414-421

Pelletier NL, Tydmers PH, Sonesson U, Scholz AJ, Ziegler F, Flysjo A, Kruse SA, Cancino B, Silverman H (2009) Not all salmon are created equal: life cycle assessment (LCA) of global salmon farming systems. Environ Sci Technol 43:8730-8736

Pfister S (2017) Understanding the LCA and ISO water footprint: a response to Hoekstra (2016) "a critique on the water-scarcity weighted water footprint in LCA". Ecol Indic 72:352-359

Pfister S, Koehler A, Hellweg S (2009) Assessing the environmental impacts of freshwater consumption in LCA. Environ Sci Technol 43:4098-4104

Pfister S, Bayer P, Koehler A, Hellweg S (2011) Projected water consumption in future global agriculture: scenarios and related impacts. Sci Total Environ 409:4206-4216

Pfister S, Vionnet S, Levova T, Humber S (2016) Ecoinvent 3: assessing water use in LCA and facilitating water footprinting. Int J Life Cycle Assess 21:1349-1360

Roberts CA, Newton RW, Bostock JC, Prescott SG, Honey DJ, Telfer TC, Walmsley SF, Little DC, Hull SC (2015) A risk benefit analysis of Mariculture as a means to reduce the impacts of terrestrial production of food and energy. A study commissioned by the Scottish aquaculture research forum (SARF). http://www.sarf.org.uk/212pp

Robinson TP, Thornton PK, Franceschini G, Kruska RL, Chiozza F, Notenbaert A, Cecchi G, Herrero M, Epprecht M, Fritz S, You L, Conchedda G, See L (2011) Global livestock production systems. 
Food and Agriculture Organization of the United Nations (FAO), Rome and International Livestock Research Institute (ILRI), 152 pp

Schlich EH, Fleissner U (2005) The ecology of scale: assessment of regional energy turnover and comparison with global food. Int $\mathrm{J}$ Life Cycle Assess 10(3):219-223

Schmidt JH (2010) Comparative life cycle assessment of rapeseed oil and palm oil. Int J Life Cycle Assess 15:183-197. Springer

SEPA (2004) Evaluation of fish waste manage techniques. SEPA contract reference 230/4198. Scottish Environmental Protection Agency, Edinburgh 48pp

Spinelli D, Jez S, Pogni R, Basosi R (2013) Environmental and life cycle analysis of a biodiesel production line from sunflower in the province of Siena (Italy). Energ Policy 59:492-506

Spugnoli P, Dainelli R, D’Avino L, Mazzoncini M, Lazzeri L (2012) Sustainability of sunflower cultivation for biodiesel production in Tuscany within the EU renewable energy directive. Biosyst Eng $112: 49-55$

SSPO (2015) Sustainable Scottish Salmon Scottish Salmon farming economic report June 2015. Scottish Salmon Producers' Organisation, Perth, $16 \mathrm{pp}$

Statistics Norway (2009) Fishery statistics 2007, official statistics of Norway D 428. Statistics Norway, Oslo, 13 pp

Tacon AGJ, Metian M (2015) Feed matters: satisfying the feed demand of aquaculture. Rev Fish Sci Aqua 23:1-10

Torres SM, Moran EF, Silva RFB (2017) Property rights and the soybean revolution: shaping how China and Brazil are Telecoupled. Sustainability 9:954 MDPI, Basel Switzerland
Torrisen O, Olsen RE, Toresen R, Hemre GI, Tacon GJ, Asche F, Hardy RW, Santosh L (2011) Atlantic Salmon (Salmo Salar): the "superchicken" of the sea? Rev Fish Sci 19(3):257-278

Tritsch I, Arvor D (2016) Transition in environmental governance in the Brazilian Amazon: emergence of a new pattern of socio-economic development and deforestation. Land Use Policy 59:446-455

Troell M, Metian M, Beveridge M, Verdegem M, Deutsch L (2014a) Comment on 'water footprint of marine protein consumption - aquaculture's link to agriculture' environ res Lett 9:1-4

Troell M, Naylor R, Metian M et al (2014b) Does aquaculture add resilience to the global food system? Proc Natl Acad Sci U S A 111: $13257-13263$

UNEP (2000) Cleaner production assessment in fish processing. Report prepared by COWI consulting engineers and planners AS, Denmark on behalf of United Nations Environment Programme Division of Technology, Industry and Economics and Danish Environmental Protection Agency, $99 \mathrm{pp}$

Wang T, Li X, Gong T, Zhang H (2014) Life cycle assessment of wheatmaize rotation system emphasizing high crop yield and high resource use efficiency in Quzhou County. J Clean Prod 68:56-63

Williams AG, Audsley E, Sandars DL (2010) Environmental burdens of producing bread wheat, oilseed rape and potatoes in England and Wales using simulation and system modelling. Int J Life Cycle Assess 15:855-868

Ziegler F, Hornborg S, Green BS, Eigaard OR, Farmery AK, Hammar L, Hartmann K, Molander S, Parker RWR, Hognes ES, Vazquez-Rowe I, Smith ADM (2016) Expanding the concept of sustainable seafood using life cycle assessment. Fish Fish 17:1073-1093 